\title{
An Overview of Recent Changes in the Global Maritime Distress and Safety System Regarding Maritime Mobile Satellite Service
}

\section{Pregled nedavnih promjena u Svjetskom pomorskom sustavu pogibelji i sigurnosti vezanih uz pomorske pokretne satelitske usluge}

\author{
Sanjin Valčić \\ University of Rijeka \\ Faculty of Maritime Studies \\ E-mail: svalcic@pfri.hr
}

\author{
Srđan Žuškin \\ University of Rijeka \\ Faculty of Maritime Studies \\ E-mail: szuskin@pfri.hr
}

\author{
David Brčić \\ University of Rijeka \\ Faculty of Maritime Studies \\ E-mail: brcic@pfri.hr
}

\author{
Davor Šakan \\ University of Rijeka \\ Faculty of Maritime Studies \\ E-mail: sakan@pfri.hr
}

\section{Summary}

For a long time, Inmarsat satellite system was the only maritime mobile satellite service provider when Global Maritime Distress and Safety System (GMDSS) is concerned. This satellite system has different generations of its satellites providing a wide range of services and applications. In 2018, its services related to the GMDSS have migrated to a newer generation of satellites. This satellites' services migration is systematically discussed and analysed in this paper in order to familiarize the readers with its effects on the safety of navigation. Furthermore, Inmarsat system announced a new service called Inmarsat Fleet Safety which will incorporate and provide all functional requirements for the GMDSS which are currently provided by Inmarsat- $C$ and Inmarsat Fleet $\mathbf{7 7}$ terminals. However, in $\mathbf{2 0 1 8}$ a new satellite system called Iridium has been recognized as a mobile satellite communication services provider in the GMDSS. Accordingly, this system and its capabilities are also introduced and briefly described in this paper. In addition, authors have discussed impacts of the introduction of the new satellite system as a service provider in the GMDSS and addressed several emphasized issues related to this GMDSS modernization.

\begin{abstract}
Sažetak
Dugo je satelitski sustav Inmarsat bio jedini pružatelj pokretnih satelitskih usluga u pomorstvu kada je u pitanju Svjetski pomorski sustav pogibelji i sigurnosti (Global Maritime Distress and Safety System - GMDSS). Ovaj satelitski sustav ima različite generacije svojih satelita koji pružaju širok spektar usluga i aplikacija. Njegove usluge vezane uz GMDSS 2018. godine preselile su se na noviju generaciju satelita. Migracija ovih satelitskih usluga sustavno se razmatra i analizira u ovom radu kako bi se čitatelji upoznali s njezinim učincima na sigurnost plovidbe. Nadalje, Inmarsat sustav najavio je novu uslugu pod nazivom Inmarsat Fleet Safety, koja će sadržavati i pružiti sve funkcionalne zahtjeve za GMDSS koji se trenutno pružaju Inmarsat-C i Inmarsat Fleet 77 terminalima. Međutim, 2018. godine novi satelitski sustav zvan Iridium prihvaćen je kao pružatelj pokretnih satelitskih komunikacijskih usluga u GMDSS-u. Sukladno s time, ovaj sustav i njegove mogućnosti također se predstavljaju i ukratko opisuju u ovom radu. Osim toga, autori detaljno analiziraju učinke uvođenja novog satelitskog sustava kao davatelja usluga u GMDSS-u te obraćaju pozornost na nekoliko istaknutih pitanja u vezi s ovom modernizacijom GMDSS- $a$.
\end{abstract}

DOI 10.17818/NM/2019/3.6 UDK $347.79 * 654.93 * 656.61$

Review / Pregledni rad

Paper accepted / Rukopis primljen: 16. 5. 2019.

\section{KEY WORDS}

GMDSS

Maritime Mobile Satellite Service Inmarsat

Iridium

KLJUČNE RIJEČI
GMDSS
pomorske pokretne satelitske usluge
Inmarsat
Iridium

\section{INTRODUCTION / Uvod}

The GMDSS system has been adopted and the Safety of Life at Sea (SOLAS) Convention has been amended simultaneously back in 1988. However, it has been fully implemented onboard vessels in 1999. From that time, according to the GMDSS, the maritime mobile satellite services are provided by the Cospas-
Sarsat and Inmarsat systems. Since the Cospas-Sarsat system is intended only for the Search and Rescue (SAR) applications, i.e. for the provision of distress alerting and locating, the Inmarsat system was the only satellite system for providing other communication functions of the GMDSS, such as the 


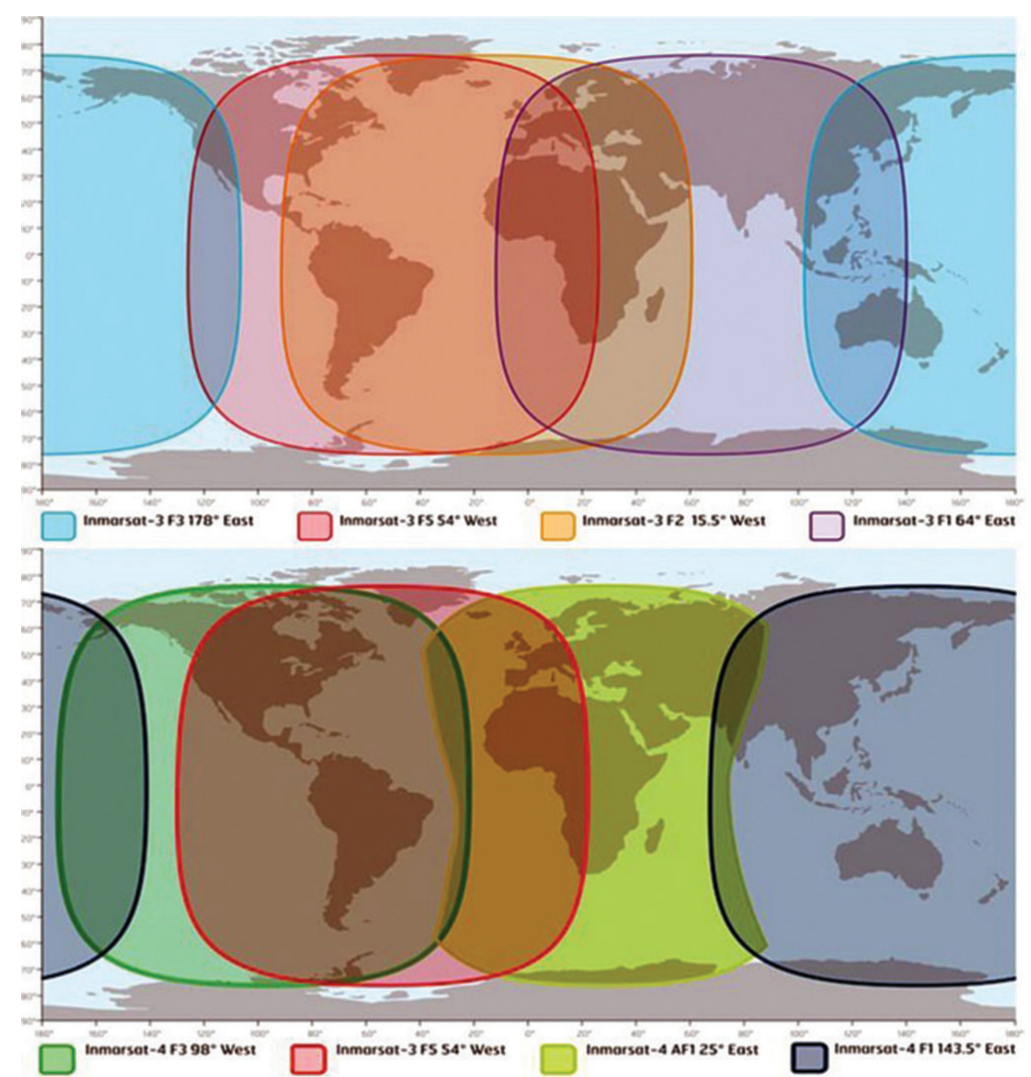

Source: [6]

Figure 1 Inmarsat satellite coverage areas before (above) and after (below) the migration process Slika 1. Područja pokrivanja Inmarsat satelita prije (iznad) i poslije (ispod) migracijskog procesa

promulgation of Maritime Safety Information (MSI) and general communications. Therefore, the GMDSS sea area A3 is defined as the coverage area of the geostationary, i.e. Inmarsat satellites, excluding sea areas $\mathrm{A} 1$ and $\mathrm{A} 2$, which are defined by the coverage of radio signals from terrestrial VHF and MF coast radio stations with continuous DSC watch. Currently in the geostationary orbit there are various generations of operational Inmarsat satellites. The oldest are the satellites of the $3^{\text {rd }}$ generation, which have partially reached the end of their lifespan at the end of 2018. The maritime industry should be aware of this information, since the GMDSS approved Inmarsat Ship Earth Stations (SESs) were linked through these satellites.

The benefits of Global Navigation Satellite Systems' (GNSS) are recognized as well. Development of Medium Earth Orbit SAR (MEOSAR) segment represents a reasonable path towards enhanced distress and SAR communications, including technologies as Return Link Services (RLS) and Distress Alerting Satellite System (DASS). As to date present, the SAR service is provided by Galileo satellite navigation system (SNS) solely, although its full operability is expected in 2020. This is the year when a full MEOSAR transition is expected, including GLONASS and GPS MEOSAR services [13].

On its fourth session, the International Maritime Organization's (IMO) Sub-Committee on Navigation, Communications and Search and Rescue (NCSR) has provided a draft of the modernization plan for the GMDSS [3]. One of the components of the proposed modernization plan is the provision of new GMDSS satellite services and redefinition of Sea Area 3 [11]. These new GMDSS satellite services imply the possible introduction and adoption of new satellite systems as providers of GMDSS communication functions.
As the research problem is introduced, the paper is organized as follows. After the Introduction, the analysis of impacts of the Inmarsat satellite migration on the GMDSS is provided together with the introduction of the new Inmarsat Fleet Safety service. Then, the systematic and detailed description of the Iridium satellite system is given, following the discussion section and conclusions.

\section{THE IMPACT OF THE INMARSAT SATELLITE MIGRATION PROCESS ON THE GMDSS / Utjecaj migracijskog procesa Inmarsat satelita na GMDSS}

In 2018 Inmarsat announced the transition of its services, including services related to the GMDSS, onto the next generation of satellites [6][7][8].

The first step of the Inmarsat services' migration process was the transition of the Inmarsat Atlantic Ocean Region West (AOR-W) $3^{\text {rd }}$ generation satellite (at the $54^{\circ} \mathrm{W}$ ) services to the Inmarsat Americas (AMER) $4^{\text {th }}$ generation satellite (at the $98^{\circ} \mathrm{W}$ ), which was successfully completed on the May 9, 2018.

The second step was the migration of the Inmarsat Pacific Ocean Region (POR) $3^{\text {rd }}$ generation satellite (at the $178^{\circ} \mathrm{E}$ ) services to the Inmarsat Asia/Pacific (at the APAC) $4^{\text {th }}$ generation satellite (at the $143.5^{\circ} \mathrm{E}$ ), which was successfully completed on the August 29, 2018.

The next step was the service migration of the Inmarsat Atlantic Ocean Region East (AOR-E) $3^{\text {rd }}$ generation satellite (at the $15.5^{\circ} \mathrm{W}$ ) to the previously mentioned Inmarsat Atlantic Ocean Region West (AOR-W) $3^{\text {rd }}$ generation satellite (at the $54^{\circ} \mathrm{W}$ ), which was successfully completed on the October 30 , 2018. This $3^{\text {rd }}$ generation satellite remains the only operational satellite of this generation. 
The fourth and the last step was the migration of the Inmarsat Indian Ocean Region (IOR) $3^{\text {rd }}$ generation satellite (at the $64^{\circ} \mathrm{E}$ ) services to the Inmarsat Europe/Middle East/Africa (EMEA) $4^{\text {th }}$ generation satellite (at the $25^{\circ} \mathrm{E}$ ). This migration process was successfully completed on the December 12, 2018. As it can be seen on the Figure 1, the coverage areas of the AOR-W, AOR-E, IOR and POR are moved to the west after the migration process.

As it was previously stated, according to the GMDSS, the sea area $\mathrm{A} 3$ is defined by the coverage of the geostationary, i.e. Inmarsat satellites (excluding sea areas A1 and A2). In this area vessels can be equipped with the GMDSS approved Inmarsat SESs, which are currently only the Inmarsat- $C$, the Inmarsat Fleet 77 (whose services are intended to be closed at the end of 2020) and the Enhanced Group Call (EGC) receiver, which is usually integrated in the Inmarsat-C SES, for the international SafetyNET service.

After the aforementioned satellite migration, the names and abbreviations of the ocean regions remain the same when using the GMDSS approved SESs. However, since the coverage area of each ocean region has been changed, the Inmarsat-C SESs can be out of the coverage of the satellite to which they were logged in. In that case the GMDSS approved terminals of the Inmarsat-C
SESs must provide an alarm and demand the operator's manual log in process. Furthermore, as before the migration, the GMDSS approved Inmarsat-C SESs will always send the distress alerts, regardless of being logged in or out of the ocean region. In addition, sending the distress alerts did not change and is not affected by the migration process neither for the Inmarsat- $C$ nor Inmarsat Fleet 77 SES. The distress alerts are still received and processed by the Land Earth Stations (LESs) in each ocean region and are automatically forwarded, with the highest priority, to the associated Maritime Rescue Coordination Centre (MRCC). The identifications and locations of all the available LES and their service providers can be found in Table 1 [4].

Regarding and depending on the type of the Inmarsat Fleet 77 SES, which does not need the log in or log out process as the Inmarsat-C SES, another ocean region can be selected automatically. However, if the location of the $4^{\text {th }}$ generation satellite is not known by some Inmarsat Fleet 77 SESs, it is necessary to perform the so called sky search protocol during which SES scans the strongest satellite signal. In addition, regarding the Inmarsat Fleet 77 services, the protocol called Mobile Packet Data Service (MPDS), which is used for the data exchange, is no longer available on the new satellite constellation.

Table 1 The identifications and locations of the all available LES operators [4] Tablica 1. Oznake i lokacije svih raspoloživih LES operatera [4]

\begin{tabular}{|c|c|c|c|c|c|}
\hline Country & LES Name & Region & LES Service Provider & LES ID & $\mathrm{RCC}$ \\
\hline \multirow{8}{*}{ Netherlands } & \multirow{8}{*}{ Burum } & AOR-W & \multirow{8}{*}{ Inmarsat Solutions } & 002 & MRCC Falmouth \\
\hline & & AOR-W & & 012 & JRCC Den Helder \\
\hline & & AOR-E & & 102 & MRCC Falmouth \\
\hline & & AOR-E & & 112 & JRCC Den Helder \\
\hline & & POR & & 202 & MRCC Falmouth \\
\hline & & POR & & 212 & RCC Australia \\
\hline & & IOR & & 302 & MRCC Falmouth \\
\hline & & IOR & & 312 & RCC Australia \\
\hline \multirow{8}{*}{ Norway } & \multirow{8}{*}{ Eik } & AOR-W & \multirow{8}{*}{ Comsat, Marlink } & 001 & USCG Norfolk \\
\hline & & AOR-W & & 004 & JRCC Stavanger \\
\hline & & AOR-E & & 101 & USCG Norfolk \\
\hline & & AOR-E & & 104 & JRCC Stavanger \\
\hline & & POR & & 201 & USCG Alameda \\
\hline & & POR & & 204 & JRCC Stavanger \\
\hline & & IOR & & 301 & JRCC Stavanger \\
\hline & & IOR & & 304 & JRCC Stavanger \\
\hline \multirow{4}{*}{ Japan } & \multirow{4}{*}{ Yamaguchi } & AOR-W & \multirow{4}{*}{ KDDI } & 003 & Operations Centre, Tokyo \\
\hline & & AOR-E & & 103 & Operations Centre, Tokyo \\
\hline & & POR & & 203 & Operations Centre, Tokyo \\
\hline & & IOR & & 303 & Operations Centre, Tokyo \\
\hline \multirow{2}{*}{ Italy } & \multirow{2}{*}{ Fucino } & AOR-E & \multirow{2}{*}{ Telecom Italia } & 105 & CG Rome \\
\hline & & IOR & & 335 & CG Rome \\
\hline India & Pune & IOR & TATA & 306 & MRCC Mumbai \\
\hline \multirow{2}{*}{ China } & \multirow{2}{*}{ Beijing } & POR & \multirow{2}{*}{ MCN } & 211 & MRCC Beijing \\
\hline & & IOR & & 311 & MRCC Beijing \\
\hline \multirow{2}{*}{ Russian Federation } & \multirow{2}{*}{ Nudol } & POR & \multirow{2}{*}{ Marsat } & 217 & MRCC Vladivostok \\
\hline & & IOR & & 317 & MRCC Moscow \\
\hline \multirow{4}{*}{ France } & \multirow{4}{*}{ Aussaguel } & AOR-W & \multirow{4}{*}{ Marlink } & 021 & CROSS Griz-Nez \\
\hline & & AOR-E & & 121 & CROSS Griz-Nez \\
\hline & & POR & & 221 & CROSS Griz-Nez \\
\hline & & IOR & & 321 & CROSS Griz-Nez \\
\hline Vietnam & Hai Phong & IOR & Vishipel & 330 & MRCC Vietnam \\
\hline
\end{tabular}




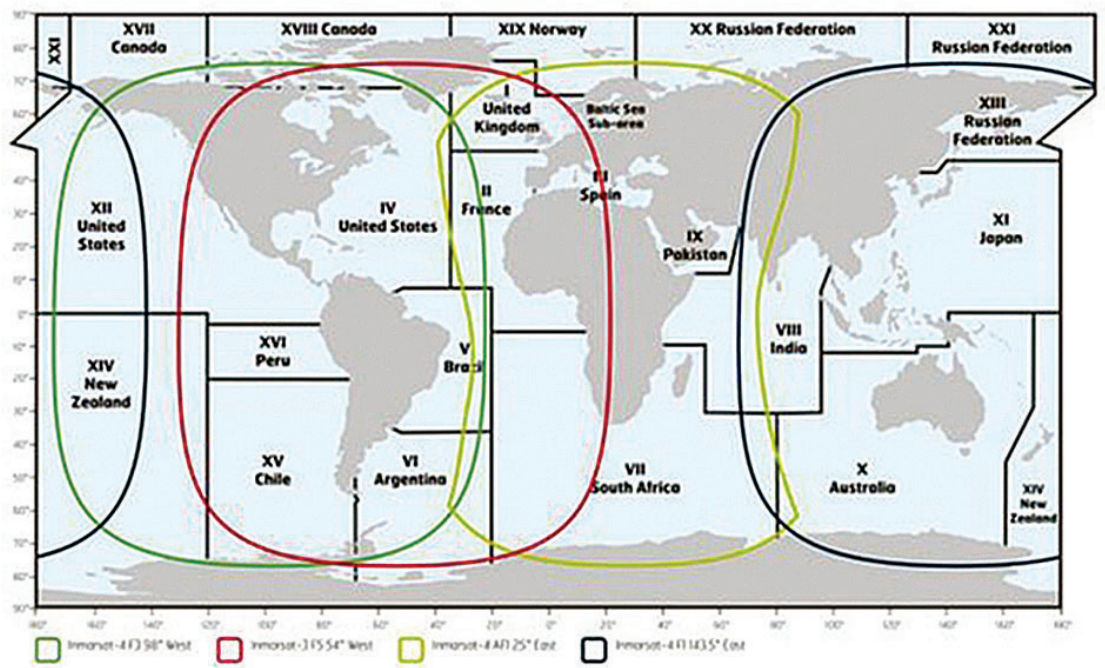

Source: [6]

Figure 2 Inmarsat satellite coverage of NAVAREAs/METAREAs after the migration process Slika 2. Inmarsatova pokrivenost NAVAREA/METAREA područja nakon migracijskog procesa

The migration process does not have the impact on the reception of the Maritime Safety Information (MSI) through the international SafetyNET broadcasting service using the onboard EGC receiver. However, SafetyNET information providers, such as NAVAREA Coordinators, METAREA Issuing Services and MRCCs which broadcast EGC messages through the LESs, need to ensure that MSI messages will be broadcasted over the correct satellite(s) to their areas of responsibility, such as Navigational and Meteorological Areas (METAREAs/NAVAREAs). Satellite coverage of NAVAREAs/METAREAs, after the migration process, can be found on the Figure 2.

However, as an alternative, any certified SafetyNET user could use the next generation, i.e. the SafetyNET II service which does not need the operator's intervention. The SafetyNET II is an improvement to the current SafetyNET service which provides a user friendly and interactive web interface for MSI providers to make and transmit MSI messages simultaneously over InmarsatC's EGC receiver and also the new maritime mobile satellite service called Inmarsat Fleet Safety. Namely, the Maritime Safety Committee (MSC) has currently recognized this service only under the coverage area of the Inmarsat Middle East and Asia (MEAS) 4th generation satellite (at the $64^{\circ} \mathrm{E}$ ), since it is the only one that has the required spare satellite. The coverage area of the Inmarsat MEAS satellite can be seen on Figure 3 [1]. The Fleet Safety SES consists of Fleet Broadband terminal (FBB), Maritime Safety Terminal (MST) with the EGC receiving capability, Dedicated Distress Button, printer and keyboard and it is expected to be commercially available at the end of 2019.

After the migration process, a particular attention must be paid when considering applications such as Long Range Identification and Tracking (LRIT) and Vessel Monitoring System (VMS). Namely, these applications use data reporting and polling, an optional services of Inmarsat-C SES in order to identify and track the position and movement of vessels. In order to provide data reports, an Inmarsat-C SES needs to be assigned with a member number into a closed user group which has a specific Data Network Identifier (DNID). This closed user group is defined by the LESID and the ocean region, i.e. by the satellite. The DNIDs can be found in the memory of every SES and for every ocean region. Sending data reports depends on the DNIDs and associated parameters configured for

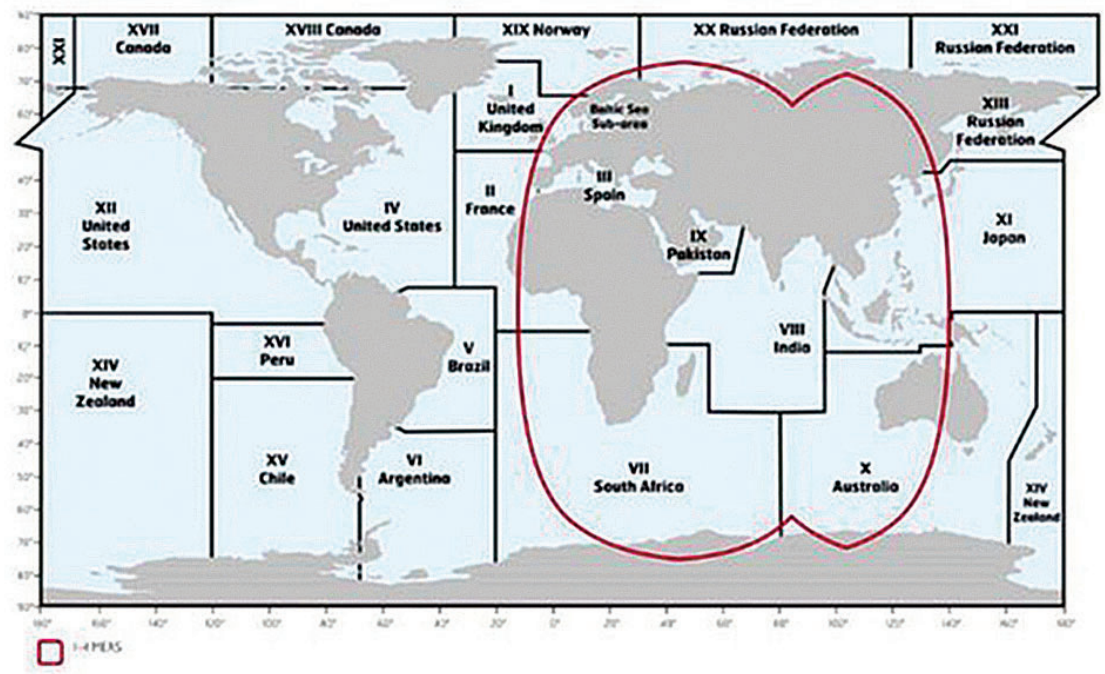

Source: [1]

Figure 3 Coverage area of Inmarsat MEAS satellite Slika 3. Pokrivenost Inmarsat MEAS satelita 
the specific ocean region. A particular DNID configuration may not be available in some SES for all ocean regions so data reporting can be different for each ocean region. Consequently, if a SES is not configured for the particular DNID, or is configured differently for the new ocean region (after the migration), the terminal could stop sending data reports [6].

Another possible and supported usage of the Inmarsat- $C$ SES is the Ship Security Alert System (SSAS), a silent alerting application which is based on sending distress alert to a number of preconfigured destinations. This application uses Inmarsat-C SES store-and-forward messaging with normal priority sending. The satellite migration has no impact on this application, providing the $\mathrm{SES}$ is logged into an ocean region [6].

\section{THE IRIDIUM SATELLITE SYSTEM / Satelitski sustav Iridium}

The Iridium satellite system, as any other satellite system, consists of three segments: space or satellite segment; ground segment; and users. The space or satellite segment consists of 66 operational Low Earth Orbit (LEO) satellites and additional 6 spare satellites in each orbit. These satellites are evenly distributed in six orbital planes at an altitude of $780 \mathrm{~km}$ with a polar $\left(86.4^{\circ}\right)$ inclination and completely orbit the Earth in a period of approximately 100 minutes (Figure 4).

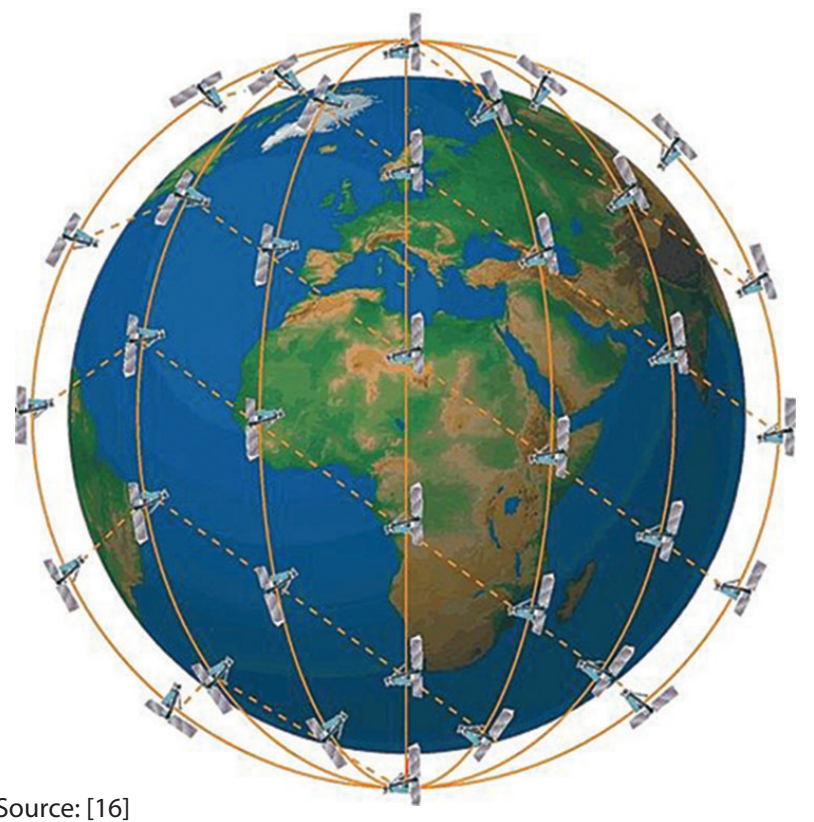

Figure 4 Iridium satellite constellation

Slika 4. Konstelacija satelita Iridium sustava

The Iridium satellites provide three types of communication links: satellite-to-satellite, satellite-to-ground, and satellite-tomobile earth stations, i.e. users. Each satellite is linked with the satellite immediately ahead and behind in its orbital plane (North or South) and to the nearest satellite in each of the two adjacent orbital planes (East or West). The Iridium system is the only mobile satellite system employing this cross-linked satellite arrangement. As a result, a mobile earth station is not required to be within the same satellite coverage as a ground segment in order to make a connection. This arrangement provides a fully global coverage and operation [5].

Each operational satellite has an overall coverage area on the Earth's surface with a diameter of approximately 4,500 km. In addition, each satellite can form 48 spot beams (footprints), each covering the Earth's surface with diameter of approximately 400 $\mathrm{km}$. This means that spot beams mutually overlap, as well as the spot beams from adjacent satellites. The Iridium satellite system dynamically uses the most appropriate combination of spot beams and satellites for the selected and appropriate area(s). Namely, about once every minute, the communication cell for a mobile earth station is provided by a different spot beam on the same satellite and about once every six minutes the communication cell is provided by a spot beam on an adjacent satellite. The so called "handoff" special processing ensures that communication links are being maintained [5].

The ground segment consisting of the gateways which act as switches providing a connection to terrestrial voice and data networks, and the so called satellite teleports for the exchange of data and voice communications between the gateways and satellites. Furthermore, the Satellite Network Operations Centre (SNOC) manages the satellite constellation and the network of the entire Iridium system. The SNOC is linked with the satellites through the Telemetry, Tracking and Control (TTAC) facilities. In addition to controlling communications between the SNOC and the satellites, the TTAC facilities track the Iridium satellites and receive telemetry data from them [5] [15].

In addition to the new satellite service of Inmarsat system, the MSC also agreed that the Iridium satellite system has satisfied all the criteria to be recognized as a mobile satellite communication services provider in the GMDSS, which include the Iridium Safety Voice, Short-Burst Data and EGC services [2]. Currently, only the draft operational manual for the Iridium EGC service has been produced and is yet to be approved. It is stated that the Iridium global satellite EGC system is a satellite-based service for the promulgation of MSI, navigational and meteorological warnings, meteorological forecasts, SAR information and other urgent safety-related messages to ships. In addition, the Iridium satellite system will allow calls regarding maritime safety communications in ship-to-shore, shore-to-ship and ship-to-ship direction (trough satellite links). Moreover, as the Inmarsat system, the Iridium satellite system will also provide for four levels of calls prioritization (distress, urgency, safety and routine/other) and will perform a pre-emption of lower priority communications [5] [14].

\section{DISCUSSION / Rasprava}

All the above facts clearly indicate that the GMDSS has been modernized considering maritime mobile satellite service and that SOLAS Convention needs to be amended to incorporate this modernization. The recognition of the new satellite system, Iridium, as a GMDSS service provider, has imposed a change in the definition of the GMDSS sea areas, particularly areas A3 and A4. Namely, the GMDSS sea area A4 is by the current definition a navigational area not covered by the terrestrial VHF and MF radio signals from coast radio stations (with a continuous DSC watch) nor by the geostationary Inmarsat satellites. This area represents parts of the Earth's poles covered only by the satellites of the Iridium system. In that respect, the Iridium satellite system is the only satellite system covering the entire globe. This also includes the GMDSS sea area A3.

When considering navigation areas that are not included in the terrestrial NAVTEX system, the MSI must be distributed by using the International SafetyNET service for distances up to 250 NM from the coast [12]. In the last two decades this has been provided by the Inmarsat's EGC system. However, with the introduction of the new 
Iridium global satellite EGC system, the area for distributing the MSI has been expanded. This is particularly important for NAVAREA(s)/ $\operatorname{METAREA}(s)$ in the Arctic region, which are currently covered only by the terrestrial NAVTEX system, since there is no Inmarsat satellite coverage (Figure 2).

Recognition of Iridium as second GMDSS satellite services provider will enhance maritime safety and commercial communications. Nevertheless, there are several issues that must be addressed: availability of GMDSS terminals, service optionality, MSI promulgation and radio regulation changes.

The expected start of Iridium GMDSS services is early 2020. Still, there aren't any commercially available GMDSS terminals. However, Iridium supported terminal was made by Lars Thrane communication systems in late 2017 and tested for the International Mobile Satellite Organization (IMSO). The planned LT-3200 terminal is based on existing non-GMDSS LT-3100 Iridium terminal and it is yet to be type approved [17].

There are also uncertainties regarding implementation and optionality of Iridium services and equipment. Will these services and complementary equipment be mandatory or optional, just as present GMDSS area A3 and A4 options? If optional, this could lead to several GMDSS compliance solutions for the ship owners and reflect in possible approaches of equipment development for the manufacturers. Iridium states that approximately $20 \%$ of SOLAS vessels have non-GMDSS Iridium equipment [10]. Since Iridium's only terminal is currently being developed, the first available solution would be a dedicated Iridium terminal installation to existing GMDSS equipment. Second approach would include integrated L-band terminals for both Inmarsat and Iridium systems. This approach would reduce number of terminals and equipment on board. Nevertheless, this approach would have to deal with system operational differences, procedures and terminology. Both solutions contribute to the complexity of exiting GMDSS procedures.

The promulgation of MSI messages is mandatory through all mobile satellite systems [9]. This increases the fail-safety of the message reception, however contributes to message redundancy. Currently, Iridium EGC manual is still under development and possible interoperability between mobile satellite service is not considered. An integrated approach would resolve possible multiple reception of the same MSI messages.

Addition of the Iridium as a maritime mobile satellite provider has resulted in discussion on current L-band frequency allocations and possible interferences for the various services in the L-band, e.g. GNSS [18]. These issues will be discussed as the part of the Agenda item 1.8 of for the WRC-19 conference.

\section{CONCLUSION / Zaključak}

The introduction and acceptance of a new satellite system as a GMDSS services provider represents a significant achievement which has ended a monopoly of the Inmarsat system as the only GMDSS satellite service provider. This will prospectively bring healthy competition in providing satellite communications to shipping companies worldwide. Thus, the Inmarsat system has already improved its satellite services by the replacement of older generation of satellites and introduced a new service called Fleet Safety.

When considering the functional requirements of the GMDSS with the regard of the Iridium satellite system, it should be recognized that the nature of the coverage area of the orbiting Iridium satellites, combined with their intersatellite transmissions, ensures that every vessel equipped with the Iridium SES will still be able to transmit distress alerts and to receive MSI or SAR communications even in the event of a satellite failure. In addition to the global Iridium coverage, this is very important difference when compared to the Inmarsat satellite system.

The introduction of these new GMDSS satellite services will result in the declining usage of the terrestrial communication systems, such as radio telex, NAVTEX and Digital Selective Calling (DSC), since their capabilities are limited when compared to satellite systems. The development of the MEOSAR segment and respective services additionally supports this statement. However, considering the most important communication function of the GMDSS, i.e. distress alerting, terrestrial communication systems will still be the primary means for ship-to-ship alerting.

The facts stated and analyzed in this paper concern the modernization of the GMDSS system with the aim of improving the safety of life at sea. Namely, the abovementioned new generation of Inmarsat satellites will provide new communication services based on the Broadband Global Area Network (BGAN) achieving data rates of up to $492 \mathrm{kbps}$ and providing services such as: E-mail and webmail, Real-time electronic chart and weather updates, Remote company intranet and internet access, Large file transfer, etc. On the other hand, the Iridium terminals will offer both commercial and safety capabilities all in one purpose-built terminal, and will deliver Distress Voice, Distress Alert and MSI.

\section{REFERENCES / Literatura}

[1] IMO Maritime Safety Committee (2018). Resolution 450 (99) - Statement of Recognition of Maritime Mobile Satellite Services Provided by Inmarsat Global Ltd.

[2] IMO Maritime Safety Committee (2018). Resolution 451 (99) - Statement of Recognition of Maritime Mobile Satellite Services Provided by Iridium Satellite LLC.

[3] IMO Sub-Committee on Navigation, Communications and Search and Rescue (2016). Draft Modernization Plan of the Global Maritime Distress And Safety System (GMDSS)

[4] IMO Sub-Committee on Navigation, Communications and Search and Rescue (2018). Developments in GMDSS Satellite Services - Analysis and assessment of the GMDSS performance of Inmarsat Global Limited

[5] IMO Sub-Committee on Navigation, Communications and Search and Rescue (2018). Updating of the GMDSS Master Plan and Guidelines on MSI (Maritime Safety Information) Provisions - Development of an Iridium EGC Manual

[6] Inmarsat (2018). I-3 to I-4 migration - Inmarsat C service guide, Version 3.0

[7] Inmarsat (2018). I-3 to I-4 migration - Inmarsat Fleet service guide, Version 2.0

[8] Inmarsat (2018). I-3 to I-4 Migration - SafetyNET, Version 2.0

[9] International Mobile Satellite Organization (2018). Implementation of the Recognized GMDSS Services by Iridium

[10] "Iridium for GMDSS, New Choice is Coming for Global Maritime Safety". https:// www.iridium.com/services/gmdss/

[11] Korcz, K. (2017). "Some Aspects of the Modernization Plan for the GMDSS". The International Journal on Marine Navigation and Safety of Sea Transportation TRANSNAV, Vol. 11, No. 1, pp. 167-174. https://doi.org/10.12716/1001.11.01.20

[12] Mikulicic, J. Z., Kasum, J., Jugovic, A. (2018). „Distribution of Maritime Safety Information and Improvement Measures for Safety of Navigation". Naše more, Vol. 65, No. 3, pp. 164-168. https://doi.org/10.17818/nm/2018/3.6

[13] O'Connors, C. (2014). MEOSAR Overview. USCG SAR Controllers Training, NOAA, 2428 March 2014, Maryland, USA, p. 28.

[14] Sekiguchi, K. (2016). "Iridium Contributes to 'Maritime Safety"'. 16th Techno-Ocean Conference (Techno-Ocean), Kobe, Japan, pp. 90-92. https://doi.org/10.1109/ techno-ocean.2016.7890625

[15] Shpilevoi, V. (2018). "Iridium as a Truly Global Mobile Satellite Network". ITU regional seminar for CIS and Europe: Development of Modern Radiocommunication Ecosystems, Sesion II: Satellite Communications, St. Petersburg

[16] "SpaceX Launches First Wave of Iridium Next Satellite Constellation Into Orbit". https://www.rvmobileinternet.com/spacex-launches-first-wave-of-iridium-nextsatellite-constellation-into-orbit/ https://doi.org/10.1063/pt.5.028908

[17] Wingrove, M. "IMO needs to approve global GMDSS safety communications". https://www.marinemec.com/news/view,imo-needs-to-approval-global-gmdsssafety-communications_51759.htm https://doi.org/10.1201/9781315099132-65

[18] World Radiocommunication Conference Advisory Committee (2017). Preliminary Views and Draft Proposals 